* Corresponding author E-mail address:maciej.rozpondek@pols.pl (Maciej Rozpondek)

Article information Article history: AMS-Volume16-No.3-00157-12 Received 6 February 2012 Accepted 15 June 2012

\section{The Analysis of Indoor Environment Parameters in Office Buildings}

\author{
Stanisław Gil ${ }^{1}$, Maciej Rozpondek ${ }^{1}$, Tomasz Grychowski ${ }^{2}$ \\ $1 G$ Goup of Process Energy, Department of Metallurgy, Silesian University of Technology, Poland \\ ${ }^{2}$ Measurement and Control System Group, Institute of Automatic Control, Silesian University of Technology, Poland
}

\section{KEY WORDS}

Energy-efficient building, thermal conditions, indoor air quality

\begin{abstract}
The current tendencies concerning optimisation of maintenance parameters with regard to thermal comfort and indoor air quality in office and commercial buildings have been presented. The heating, ventilating and cooling systems for the indoor environment design have been characterized. Results of investigations regarding the indoor environment parameters for selected, representative buildings - a traditional, modernized building and an energy-efficient building - have been compared. In the energy-efficient building, a high diversity of indoor air quality (IAQ) has been demonstrated. Effective ways of indoor environment parameter optimisation in the aspect of outdoor air stream minimisation with reduction in carbon dioxide levels regarding human-occupied areas have been proposed.
\end{abstract}

\section{Introduction}

The indoor environment of a building constitutes a separate, neighbourhood-related part of the ecosystem. Technical and thermal infrastructure of a building, i.e. primarily designs of partition walls; heating, cooling and ventilating systems as well as maintenance parameters directly affect energy consumption, indoor air quality and emission of pollution into the natural environment.

Modern construction systems aim at reducing building energy consumption, primarily by limiting the amount of energy used for heating, ventilating and air conditioning purposes [13]. Design assumptions with regard to reducing energy consumption in energy-efficient buildings, with a special emphasis on passive facilities, should aim at providing optimal indoor environment quality. Climatic conditions and thermal comfort of room users directly affect their well-being and quality of work. The basic role of ventilating systems is maintaining required indoor air quality (IAQ) parameters, which is achieved through replacing stale and polluted air with fresh air. Approximately 8000 pollutants are estimated to potentially affect the indoor air quality, including: human body odours, building materials, furniture, operating indoor appliances and outdoor pollutants [20]. Carbon dioxide concentration is assumed to be an indicator of indoor air quality and pollution in residential and office buildings which are not affected by industrial pollutants. When also outdoor air-contained pollutant (e.g. carbon dioxide) is removed, the indoor air stream value depends on the indoor $\mathrm{CO}_{2}$ stream and the difference in pollution levels of exhaust and supplied air. Therefore, current levels of carbon dioxide in the environment also should be known. The indoor $\mathrm{CO}_{2}$ levels are recommended not to exceed the Pettenkofer's maximum value of 1000 
ppm (accepted as a standard) which corresponds to about $20 \%$ of dissatisfied people according to the method developed by P.O. Fanger [1],[8],[20]. Ventilation parameters, i.e. primarily the indoor air stream and distribution, have very strong effects on the indoor environment quality and thus - efficiency of work and morbidity. It is assumed that a 5 -fold increase in the indoor air stream volume from approx. 5 to $25 \mathrm{dm}^{3} /$ (s.person) may lead to about 5-10\% better work efficiency (Fig. 1 [8], [25]).

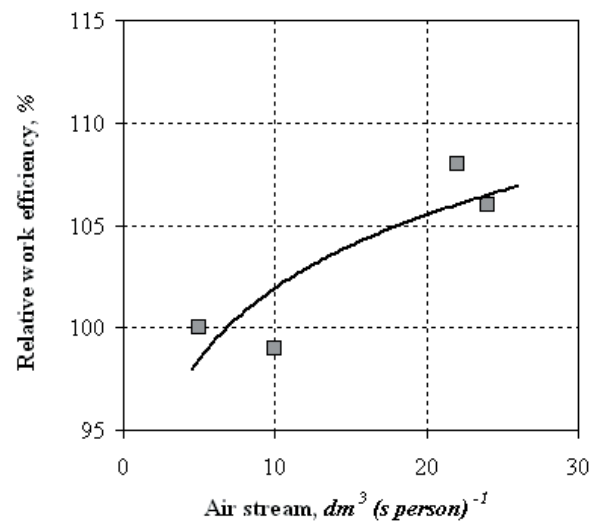

Fig. 1: Relative efficiency of office work versus a unitary indoor air volume flow [8],[25].

A particularly strong impact of the indoor air quality is seen in the case of allergy and asthma development. Intensification of air exchange from 0.17 to $0.62 \mathrm{~h}^{-1}$ results in a nearly 2 -fold lower relative risk of allergic symptom development (Fig. 2 [3], [8]).

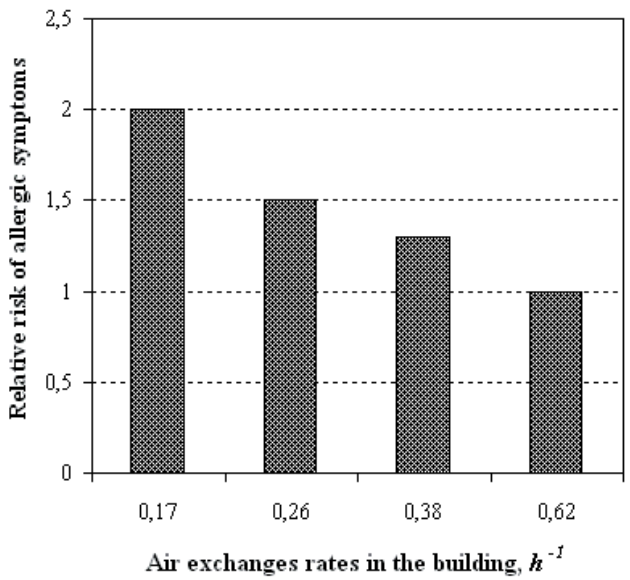

Fig. 2: Air exchanges rates versus a relative risk for allergic symptom occurrence [3],[8].
Analyses of indoor air quality levels confirmed its effects on office work, including approx. 6.5-9\% higher efficiency and lower rates of sick absence [20]. Reduction in the air temperature by $2-3 \mathrm{~K}$, e.g. from $23-24^{\circ} \mathrm{C}$ to $21^{\circ} \mathrm{C}$, may result in a twice as good perceived indoor air quality. In order to avoid draught sensation, there should be low levels of air speed and turbulence. Reduction in relative humidity down even to $20 \%$ also has a positive impact on the perceived indoor air quality [7], [8], [21], [27].

Moreover, a designer should consider a change in room utilization and introduction of another interior model, e.g. so-called open space. In fact, it is semi-open space mostly obtained through creating cubicles that impedes proper air flow. In the altered room, additional side effects are also observed, including increased morbidity, lower productivity and overlapping noise. To avoid uneven distribution of supplied and exhaust air streams in the new room structure, appropriate distances of intake and uptake ventilators should be arranged so that they are located in each new space allotted from the primary room structure.

\section{Indoor air quality parameters of office and commercial facilities}

Ventilation is aimed at providing proper indoor air quality, i.e. meeting the Pettenkofer's standard with regard to carbon dioxide levels. Moreover, ventilation parameters contribute to satisfying thermal comfort requirements for a facility. In order to maintain $\mathrm{CO}_{2} \leq 1000$ ppm in many buildings, air exchange rates in their premises should be significantly increased. For this reason, a higher carbon dioxide level (1400 or 1500 ppm) is often assumed a borderline value. The level of $2500 \mathrm{ppm}$ (maximum permissible level for CO2 is 5000 ppm) is considered harmful to health. In the paper [18], it was stated that the levels above 1250 ppm might result in unacceptable indoor air quality. In Table 1, minimum values of indoor air stream for three different levels of human activity at the carbon dioxide level of 1500 ppm are presented [2], [23].

Air exchange should be basically provided in human-occupied areas. Air flow in a room mainly depends on supply air stream parameters. For the air exchange rate of $\mathrm{n}=5 \div 10 \mathrm{~h}^{-1}$, the performance of air intake ventilators depends on their proper selection and location. For $n>10 h^{-1}$, their perfor- 
mance also depends on proper air distribution. The best conditions are close to natural conditions when people in a room experience thermal comfort through thermal balance. Thermal comfort is affected by air temperature, flow rate and humidity, which is related to the appropriate design of heating, ventilating and cooling systems. The temperature and quality of indoor air is a resultant of a building structure, heating and ventilating systems as well as outdoor parameters. For predicting and generating indoor temperature, analytical techniques based on simplified models of average temperature in a building as well as detailed techniques based on balance equations for all thermal loads in specific areas of the building are used. The air and partition wall temperatures are recommended to be comparable and the difference should not exceed 3 $\mathrm{K}$. It is assumed that temperature fluctuation above $3 \mathrm{~K}$ in a room during a day is an element of high risk for development of disease symptoms. A degree of thermal radiation asymmetry, expressed by a difference in temperature distribution in a room, should be $\Delta T \leq 10 \mathrm{~K}$ [11], [15], [19].

In passive houses, where the energy demand for heating is up to $54 \mathrm{MJ} /\left(\mathrm{m}^{2}\right.$.year) with the borderline value of peak demand for heating of $10 \mathrm{~W} / \mathrm{m}^{2}$, the requirements regarding energy demand for cooling are actually not specified. For office premises with high internal heat gains and high fractions of transparent partitions in the outer area of the building, determination of cooling demands is essential for thermal comfort. Focusing on solar energy gains during summer at high outdoor temperatures of Te $>30^{\circ} \mathrm{C}$ results in the necessity for increasing indoor temperature to $26^{\circ} \mathrm{C}$, which is difficult [9]. Helioactive elements of a building, particularly windows and glazed buffer zones, should be equipped with the following complex, additional elements that protect from solar heat gains:

- Interior elements, i.e. metal, fabric and foil blinds placed between windows as well as curtains and blinds in rooms.

- Exterior elements: sunshades, blinds, shutters, eaves as well as trees and broadleaved shrubs.

Additional thermal resistance of wooden, plate, tightly-fitted shutters is $0.7 \mathrm{~m}^{2} \cdot \mathrm{K} / \mathrm{W}$ [17].

Moreover, acoustic and proper lighting conditions (daylight and artificial light) should be considered. A human is more sensitive to temperature changes than to humidity alterations which means that \pm 1
$\mathrm{K}$ temperature changes at $2^{\circ} \mathrm{C}$ and at least $\pm 20 \%$ changes at relative humidity of $50 \%$ and the same air temperature may not be perceived [17]. It is assumed that for normally-dressed people at sedentary work, the temperature increase of $+0.5 \mathrm{~K}$ within of $23-25^{\circ} \mathrm{C}$ and the temperature decrease in the $25-27^{\circ} \mathrm{C}$ conditions are indistinguishable in terms of thermal environment [16].

In ventilating systems of buildings with chilled ceilings operating at a high level of radiative cooling, perceived temperature in a room that depends on the air temperature and surrounding partition walls is approximately lower by $2 \mathrm{~K}$ than the air temperature. Energy consumption in this system is lower than in convective systems because perceived temperature and thermal comfort are the same despite higher air temperature. During the winter season, for low levels of physical activity, the following indoor air parameters should be assumed: temperature of $20-22^{\circ} \mathrm{C}$, relative humidity of not less than 30\% for maintaining thermal comfort (according to the standards; optimal values range from 40 to $60 \%$ ) and the air flow rate of 0.2 to $0.3 \mathrm{~m} / \mathrm{s}$ [18]. Due to limited ability of human body for quick acclimatisation, it is assumed that during the summer season, a difference between the outdoor and indoor temperatures should not exceed $\Delta T=6 \div 7$ $\mathrm{K}[9],[17],[26]$. The indoor air parameters at high outdoor temperatures, i.e. $\mathrm{T}>30^{\circ} \mathrm{C}$, may be then as follows: Temperature: $\mathrm{T}_{\mathrm{i}}=24-26^{\circ} \mathrm{C}$, relative humidity: 45 to $60 \%$; and air flow rate: 0.2 to $0.3 \mathrm{~m} / \mathrm{s}$ [24].

\section{Characteristics of heating, ventilating and cooling systems in investigated office and com- mercial buildings}

Buildings selected for the study should be relatively low-energy facilities comparable to a socalled 'eco-friendly building', i.e. a pro-ecological facility which is environment- and user-friendly. These requirements with regard to energy consumption and environmental issues are met by the office and commercial building in the Euro-Centrum Science and Technology Park in Katowice. In the analysis of indoor environment, two currently most often used heating, ventilating and cooling systems of the following buildings were taken into consideration:

a conventional, modernized building with the convective heating and cooling system,

- an energy-efficient building where heating and 
cooling are supplied with the use of thermoactive $B K T$ ceilings and the underfloor heating (UH) system [4], [5].

In the conventional building, for heating and cooling purposes fan coils are applied in rooms which play a dual role, i.e. they are used for cooling in summer and for maintaining the set room temperature during the heating season. The temperature of heating agent supplied to the fan coils is controlled according to the heating curve that is related to the outdoor temperature and maintained at 70 to $30^{\circ} \mathrm{C}$. In summer, the agent's temperature is $13{ }^{\circ} \mathrm{C}$. Moreover, there are heaters installed in staircases. In order to reduce temperature during summer, a chiller (placed inside the building) is utilized. During the heating season, externally delivered thermal energy is used in all heating circuits.

In the energy-efficient building, the analysis of indoor environment parameters was performed for the heating and cooling processes in which thermoactive BKT ceilings with embedded water pipes are applied. The temperature of water circuit in the BKT system is determined by the heating (cooling) curve based on the outdoor temperature. In summer, the supply temperature of BKT system ranges from 22 to $16^{\circ} \mathrm{C}$, while during the heating season it is $30-22^{\circ} \mathrm{C}$. In winter, the underfloor heating $(\mathrm{UH})$ system is also used, but only in the ground floor rooms. The temperature of heating agent is determined by the heating curve within the same range of $30^{\circ} \mathrm{C}$ to $22^{\circ} \mathrm{C}$. In summer, chilled water (below $10^{\circ} \mathrm{C}$ ) from the lower heat source is used for reducing indoor temperature of the building. The thermal power of the cooling system is about $89 \mathrm{~kW}$ and during heatwaves it is additionally supported by the chiller (an alternative cooling source). During the heating season, BKT and UH heating circuits are supplied by thermal energy generated by the heat pump (connected to the lower source) with the maximum power of 109 $\mathrm{kW}$. During the transient period, when the central heating pump is cost-ineffective, an external connection of the maximum power $40 \mathrm{~kW}$ is utilized. Mechanical ventilation operates according to the set time programme within the time periods of day ( 6 a.m. to 6 p.m.) and night ( 6 p.m. to 6 a.m.). The night period also includes Saturday and Sunday. The air handling unit is equipped with a chiller so the air can be cooled to a set temperature, which, however, is not currently practised. The values of supply indoor air streams are $3000 \mathrm{m3n} / \mathrm{h}$ during the day and $1000 \mathrm{~m}^{3} \mathrm{n} / \mathrm{h}$ during the night.

In the conventional, modernized and the energyefficient buildings, rotary heat exchangers show very high efficiency of up to about $80 \%$ and small air flow resistivities. The heat recovery efficiency is a function of temperature recovery efficiency $(\varepsilon)$, i.e. the ratio of the interior and exterior air heat streams measured at the front and at the back of the exchanger.

According to legal requirements, heat recovery devices must be used if the mechanical supplyexhaust ventilation system of the efficiency above $10000 \mathrm{~m}^{3} / \mathrm{h}$ is applied. Despite the fact that the indoor air stream values of $3000 \mathrm{~m}^{3} / \mathrm{h}$ are below those required, a heat recovery system was used in the air handling unit. In the energy-efficient building, the indoor air recirculation ratio is up to 0.8 .

\section{Results of the study on indoor environment in office and commercial buildings: traditional, modernised building and energy-efficient building}

In Poland, the average yearly outdoor temperature is about $7.5 \pm 0.5^{\circ} \mathrm{C}$ with a $1.5 \mathrm{~K}$ higher value at the ground surface. The average yearly temperature for Katowice is about $8.1^{\circ} \mathrm{C}$. At the beginning of heating season, the outdoor temperature is approx. $10^{\circ} \mathrm{C}$, while the average outdoor temperature during this period is $+2^{\circ} \mathrm{C}$ [20]. Numbers of degree days with regard to heating (HDD) and cooling (CDD) for the period of 30 years in Katowice and Warszawa are as follows:

- HDD values (borderline value $18^{\circ} \mathrm{C}$ ): Katowice 4424, Warszawa-4372.

- $C D D$ values (borderline value $22^{\circ} \mathrm{C}$ ): Katowice 80, Warszawa - 94 [6].

The indoor environment parameters of two selected buildings in the Euro-Centrum Science and Technology Park in Katowice were investigated for the representative heating season, i.e. for outdoor temperatures of $\mathrm{Te} 1=-9^{\circ} \mathrm{C}$ and $\mathrm{Te} 2=+1.9^{\circ} \mathrm{C}$ [22]. Temperature, air flow rate and relative humidity measurements were performed with the use of TSI/AIRFLOW TA460 thermal anemometer. For temperature measurements, a thermoanemometric (resistive) sensor was used, for humidity measurements - a capacitive sensor, and for air flow rate measurements - a thermal sensor. Carbon dioxide 
measurements were performed with the use of the $\mathrm{E}+\mathrm{E}$ Elektronik EE89 sensor using the infrared absorption method.

On the ground floor of the conventional, modernized building (for office and warehouse utilization), the air parameters depended on the venti- lation parameters, while the first-floor rooms were equipped with fan coils. The results of temperature and relative humidity measurements in the modernized building are presented in Fig. 3: the ground floor (warehouse) - items 1 and 2; the first floor (rooms) - items 3 and 4.

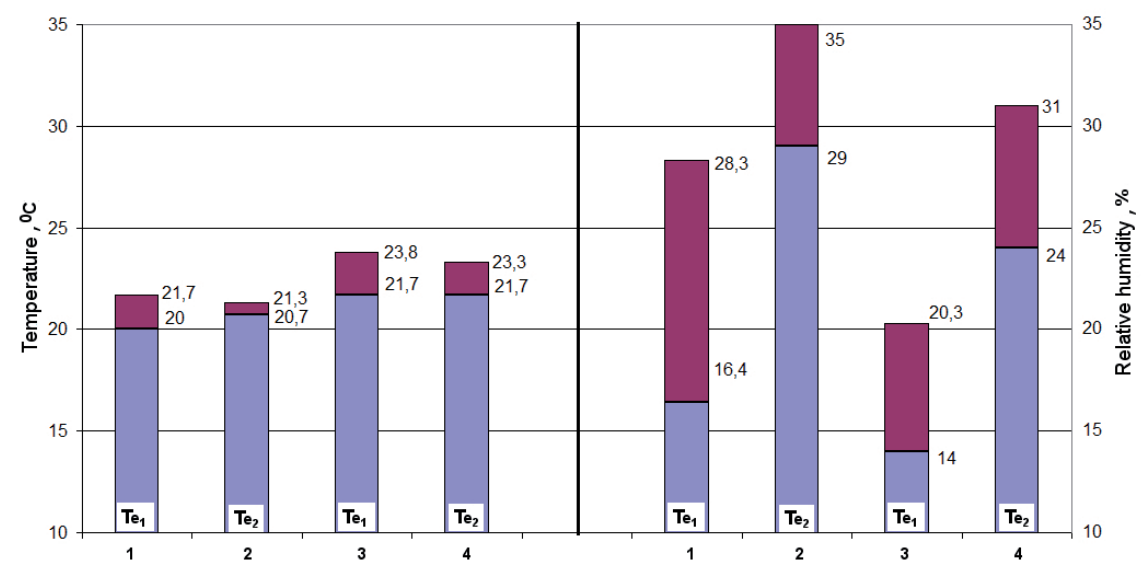

Fig. 3: Results of temperature and relative humidity in the modernized building at outdoor temperatures [22]: 1. the ground floor (warehouse): at Te1 $=-9^{\circ} \mathrm{C} ; 2$. the ground floor (warehouse): at Te2 $=+1.9^{\circ} \mathrm{C} ; 3$. rooms: at $\mathrm{Te} 1=-9{ }^{\circ} \mathrm{C} ; 4$. rooms: at $\mathrm{Te} 2=+1.9^{\circ} \mathrm{C}$.

Temperature ranges for the ground-floor facilities are about $2 \mathrm{~K}$ lower than the temperature of fan coil-equipped rooms. The lower values of relative humidity differed within 2.4 to $5 \%$, while the upper values showed a greater, significant diversity of 4 to $8 \%$. For the outdoor temperature of Te1 $=$ $-9^{\circ} \mathrm{C}$, the relative humidity values did not reach the lower value of $30 \%$ (required for the thermal comfort), while for Te $2=+1.9^{\circ} \mathrm{C}$, they were slightly above that value, i.e. the upper value was 31\% for the rooms and 35\% for the warehouse.

In the energy-efficient building where all rooms are designed for office work, the temperature and relative humidity measurements were performed in the hall and offices (Fig. 4).

The analysis of the indoor air temperatures $\mathrm{Ti}$

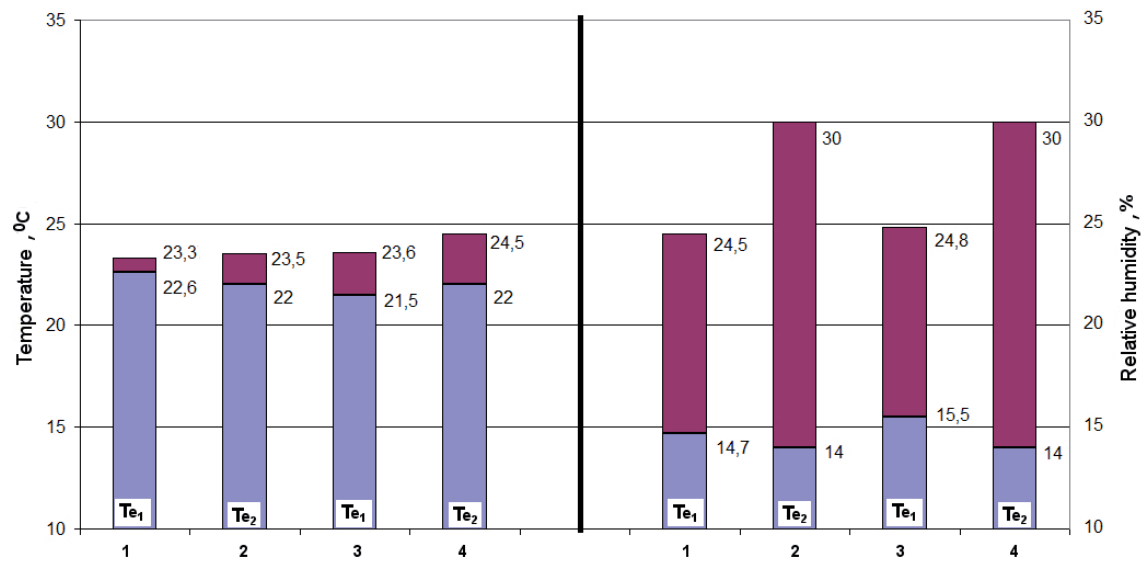

Fig. 4: Results of temperature and relative humidity in the energy-efficient building at outdoor temperatures [22]: 1. hall - at Te1 =-9० C; 2. hall - at Te2 $=+1.9^{\circ} \mathrm{C} ; 3$. rooms: at Te1 $=-9^{\circ} \mathrm{C} ; 4$. rooms: at $T e 1=+1.9^{\circ} \mathrm{C}$. 
shows that the values ranges for the hall and offices were comparable, while the lower temperature values for the offices (with fewer numbers of workers) were lower by $1 \mathrm{~K}$. Lower and upper values of relative humidity were slightly different: $0.8 \%$ and $0.3 \%$, respectively, for the outdoor temperature Te 1 $=-9{ }^{\circ} \mathrm{C}$, and they were lower by about $5 \%$ than the required value of $30 \%$. For the outdoor temperature of $\mathrm{Te} 2=+1.9^{\circ} \mathrm{C}$, humidity ranges were comparable and the upper value reached 30\%. The air flow rate values were within the lower limit of recommended maintenance range, i.e. they were 0.05 to $0.1 \mathrm{~m} / \mathrm{s}$ - optimal for the heating season. The temperature and relative humidity measurements were performed for the representative measuring cycle of the heating season in the hall and rooms on individual floors of the energy-efficient building.

With regard to the analysed buildings, additional measurements of air flow rate and $\mathrm{CO} 2$ fractions in the selected building sections were performed and the indoor air flow rate was calculated. The recommended rates of air supply from the wall- mounted intake ventilators depend on the room function and are within 0.25 to $1 \mathrm{~m} / \mathrm{s}$. The heights of analysed rooms (minimum $3.5 \mathrm{~m}$ ) facilitate higher rates of supply air up to the upper limit of 1 $\mathrm{m} / \mathrm{s}$. The results of supplied air rate measurements in the energy-efficient building range from 0.10 \pm 0.02 to $0.40 \pm 0.02$, so they are mostly near the lower limit of recommended values, and in some cases, they are even lower. The average rate of supplied air in the energy-efficient building is wa $\mathrm{e} \approx$ $0.21 \mathrm{~m} / \mathrm{s}$, while even smaller values - all below the lower limit of recommended range - are observed in the rooms of conventional, modernized building where the average rate is only wa $\mathrm{t} \approx 0.14 \mathrm{~m} / \mathrm{s}$. This factor impedes effective pollution removal from the analysed buildings, including the quantitatively largest carbon dioxide.

A mean value of carbon dioxide concentration in the analysed energy-efficient building (ca e $\approx 982$ ppm) is near 1000 ppm, while for the conventional, modernized building, the mean value is ca $t \approx 717$ ppm, i.e. far below the Pettenkofer's standard (Fig. 5).

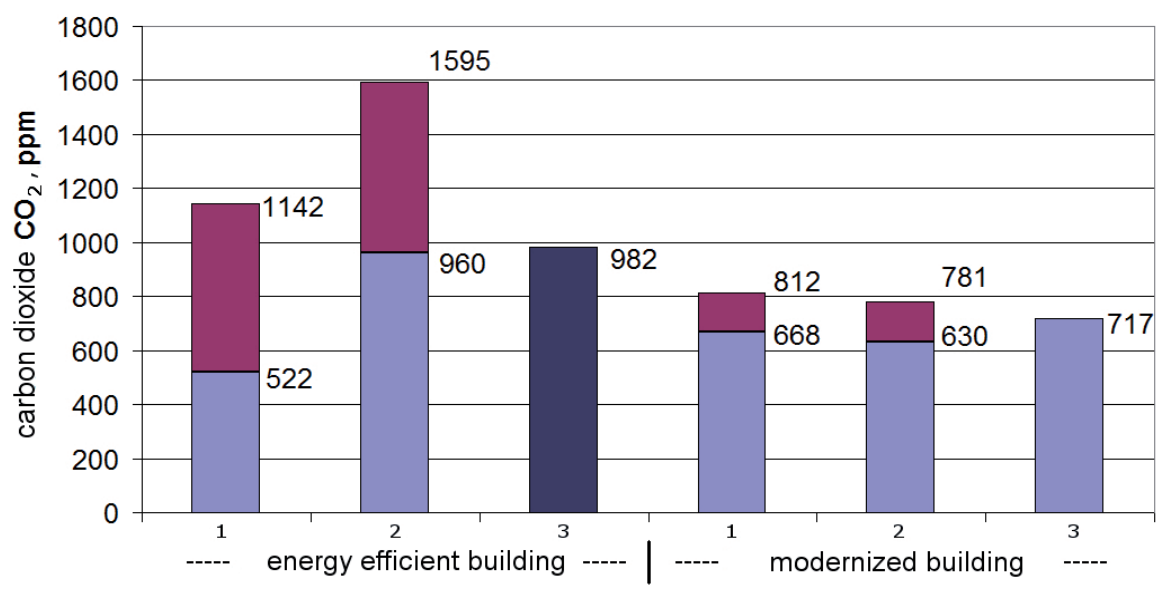

Fig. 5: Values of measured carbon dioxide concentrations in the energy-efficient and modernized buildings [22]. The energy-efficient building: 1. hall, 2. rooms, 3. the mean $\mathrm{CO}_{2}$ value in the energy-efficient building. The modernized building: 1. warehouse, 2. rooms, 3. the mean $\mathrm{CO}_{2}$ value in the modernized building.

Based on the $\mathrm{CO} 2$ emission balance for the target number of building workers and the borderline concentration of 1000 ppm $\mathrm{CO}_{2}$, a nearly real value of the maintenance indoor air stream was determined: the balance value of $5142.5 \mathrm{~m}^{3} / \mathrm{h}$ and the real maintenance value of $5000 \mathrm{~m}^{3} / \mathrm{h}$. In the conventional, modernized building, the value of determined indoor air stream with respect to the same balance methodology is about 0.45 of the real air stream: $1363.5 \mathrm{~m}^{3} / \mathrm{h}$ and $3000 \mathrm{~m}^{3} / \mathrm{h}$ for the balance and real maintenance values, respectively (Fig. 6).

This explains considerably lower carbon dioxide concentrations in the conventional, modernized rooms than those resulting from worse conditions of air flow. Both for the energy-efficient and the conventional buildings, the following parameters 
were assumed: (measured) carbon dioxide concentration in the outdoor air of $520 \mathrm{ppm}$ and the non-toxic pollution type $\psi=1$.1. In order to achieve effective reduction in air flow at maintained current carbon dioxide levels in human-occupied areas, utilization of a personalized ventilation system (PVS) based on continuous $\mathrm{CO}_{2}$ measurements with a control system using the fuzzy logic technique should be considered [10].

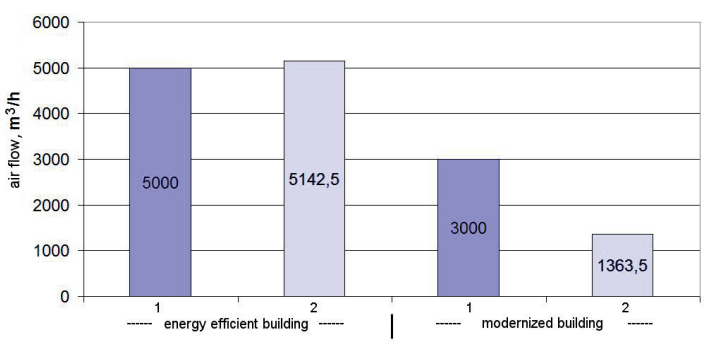

Fig. 6: Comparison of real and calculated values of indoor air streams [22]. The energy-efficient building:1. real(maintenance) indoor air flow, 2. calculated indoor air flow. The modernized building: 1.real (maintenance) indoor air flow, 2.calculated indoor air flow.

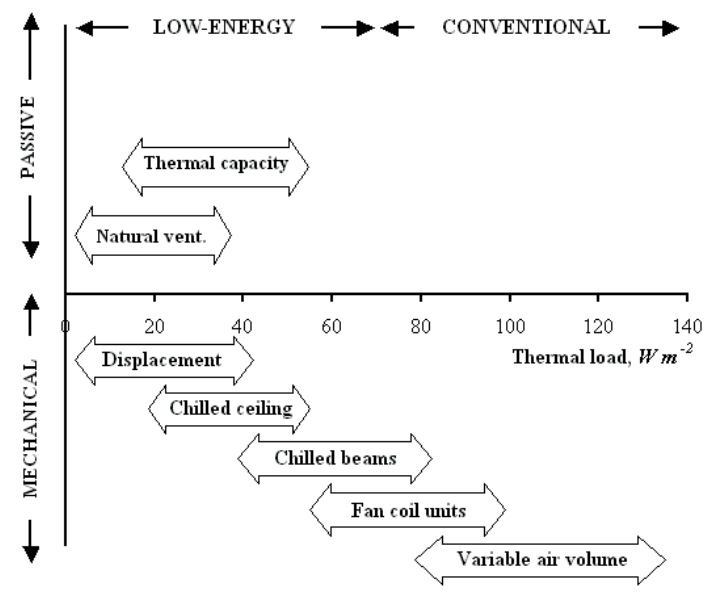

Fig. 7: Utilization of typical cooling systems in buildings. [12]

The values of real thermal load in the analysed office buildings are as follows:

- for the conventional, modernized building with the fan coil cooling system: $q \mathrm{t}=54.4 \mathrm{Wm}^{-2} \mathrm{a}^{-1}$,

- for the energy-efficient building with BKT thermoactive ceilings: $q \mathrm{e}=35,75 \mathrm{Wm}^{-2} \mathrm{a}^{-1}$.

The determined values of thermal load in the building nos. 6 and 7 were compared to the applicability ranges of cooling systems with regard to typical buildings presented in literature (Fig. 7 [12]). As evidenced by the presented relations, the thermal load value for the conventional, modernized building ( $\mathrm{q} t=54,4 \mathrm{Wm}^{-2} \mathrm{a}^{-1}$ ) is within the lower limit of fan coil cooling that ranges from about 54 to about $100 \mathrm{Wm}^{-2} \mathrm{a}^{-1}$, while for the energy-efficient building with BKT thermoactive ceilings, the respective value $\mathrm{q} e=35,75 \mathrm{Wm}^{-2} \mathrm{a}^{-1}$ is in the middle of recommended range of about 18.5 to about 56 $W m^{-2} a^{-1}$.

\section{Conclusion}

The results of study on the indoor environment parameters during the heating season in the conventional, modernized and the energy-efficient buildings show that thermal comfort conditions are met for temperature, while the relative humidity values are below the lower, so far recommended literature limit of $30 \%$. According to the current tendencies, the lower limit of relative humidity may be reduced to $20 \%$ with a positive impact on the perceived indoor air quality.

In the ventilating systems of analyzed buildings, supply and exhaust air rates should be maintained at $1 \mathrm{~m} / \mathrm{s}$, i.e. the upper limit of recommended range, which positively affects ventilation efficiency and allows for optimalisation of indoor air flow without increased carbon dioxide levels in humanoccupied areas.

The results of $\mathrm{CO}_{2}$ measurements in the energyefficient rooms show that the indoor air stream enables maintaining the average $\mathrm{CO}_{2}$ level below the Pettenkofer's standard value. In the conventional, modernized building, the value of indoor air stream is over two-fold higher than that resulting from measurement and calculation parameters based on carbon dioxide levels.

The analyzed conventional, modernized and energy-efficient buildings meet the design assumptions according to the criterion for low-energy buildings where the borderline maximum value of thermal load is $\mathrm{q} \leq 60 \mathrm{Wm}^{-2} \mathrm{a}^{-1}$.

\section{Acknowledgement}

This paper is a result of the NCRD strategic research project no. SP/B/5/68017/10 titled 'Zintegrowany system zmniejszenia eksploatacyjnej energochłonności budynków (Integrated system for reducing energy consumption in the maintenance of buildings). The research task no. 5: „Zop- 
tymalizowanie zużycia energii elektrycznej w budynkach" (Optimization of energy consumption in buildings).

\section{References}

[1] ASHRAE Standard 62:2001 Ventilation for Acceptable Indor Air Quality.

[2] Arbeitskreis der Dozenten für Klimatechnik: Handbuch der Klimatechnik, Verlag C.F. Müller, Karlsruhe, 1989.

[3] Bornehag C.G., Sundell J., Hägerhed-Engman L., Sigsgaard T.: Association between ventilation rates in 390 Swedish homes and allergic symptoms in children. 2005, Indoor Air 15 (4), pp. 275-280.

[4] Dokumentacja techniczna budynku tradycyjnym zmodernizowanym w Parku Naukowo-Technologicznym EuroCentrum w Katowicach.

[5] Dokumentacja techniczna budynku energooszczędnego w Parku Naukowo-Technologicznym Euro-Centrum w Katowicach.

[6] Dane do audytów energetycznych otrzymane z FEWE Katowice. http://www.transport.gov.pl

[7] Fang L., Wyon D.P., Fa nger P.O.: Sick building syndrome symptoms caused by low humidity. In: Tham, K.w., Sikhar, C., Cheong, D. (eds), Proceedings of Indor Buildings 2003.

[8] Fanger P., O.: Jakość powietrza wewnętrznego a zużycie energii. Energooszczędne kształtowanie środowiska wewnętrznego. Praca zbiorowa pod redakcją Popiołka Z. Politechnika Śląska - Katedra Ogrzewnictwa, Wentylacji i Techniki Odpylania, Gliwice 2005, s. 9-19.

[9] Ferdyn-Grygierek J., Baranowski A., Kaczmarczyk J.: Ocena jakości środowiska wewnętrznego i zapotrzebowania na energię do ogrzewania i chłodzenia w energooszczędnym budynku biurowym. Ciepłownictwo, Ogrzewnictwo, Wentylacja $2009 \mathrm{nr}$ 9, s. 12-17.

[10] Grychowski T.: Wspomaganie oceny komfortu cieplnego z wykorzystaniem wnioskowania rozmytego. Pomiary, Automatyka, Kontrola 9 bis (2006), 38-40.

[11] Hendiger J., Ziętek P., Chudzińska M.: Wentylacja i klimatyzacja. Materiały pomocnicze do projektowania. VentureIndustries Sp. z o.o., Warszawa 2009.

[12] Holmes M.J., Hacker J.N.: Low-energy Design Techniques for a Sustainable Future:http://nceub.commoncense.info/ uploads//HolmesHacker.pdf

[13] Horbaj P., Jasminska N.: Analysis of Economical Efficiency of Low-Temperature Heating Utilization and HW Supply in Combination with Solar Collectors in Housing and Municipal Sphere. Acta Mechanica Slovaca Vol.14 No. 01 (2010).

[14] Jones W.P.: Klimatyzacja. Wydawnictwo Arkady. Warszawa 2001.

[15] Kekkonen E., Skaret E., Sundell J., Valbjorn O.: Indoor climate problems (investigation and remedialmeasures). Nordtest
Project No. 995-91, Finland 1993.

[16] Koralik J., Olesen B., W., Toftum J.: Komfort cieplny W środowiskach z umiarkowanymi zmianami temperatury operacyjnej - obecny stan wiedzy. s. 428. (tłum. polskie) Praca zbiorowa pod redakcją Z. Popiołka: Energooszczędne kształtowanie środowiska wewnętrznego. Centrum energetycznie Efektywnych Technik i Systemów Inżynierii Środowiska Wewnętrznego. Politechnika Śląska, Gliwice 2005.

[17] Laskowski L.: Ochrona cieplna i charakterystyka energetyczna budynku. Oficyna Wydawnicza Politechniki Warszawskiej, Warszawa 2008.

[18] Lipska B., Nawrocki W.: Podstawy projektowania wentylacji - przykłady. Wydawnictwo Politechniki Śląskiej, Gliwice 1997.

[19] Nantka M.: Predykcja zmienności temperatury powietrza w budynkach i pomieszczeniach. Ciepłownictwo, Ogrzewnictwo, Wentylacja 2002 nr 2, s. 24-34.

[20] Nantka M. B.: Instalacje grzewcze i wentylacyjne w budownictwie. Wydawnictwo Politechniki Śląskiej. Gliwice 2000

[21] Niemelä R., Tuomainen M., Reijula K., Seppänen O.: Potencjalne korzyści wynikające z czyszczenia przewodów wentylacyjnych i poprawy rozdziału powietrza w budynkach biurowych. Praca zbiorowa pod redakcją Popiołka Z. Politechnika Śląska - Katedra Ogrzewnictwa, Wentylacji i Techniki Odpylania, Gliwice 2005, s. 413-417.

[22] Raport z realizacji strategicznego projektu badawczego NCBiR nr SP/B/5/68017/10. "Zintegrowany system zmniejszenia eksploatacyjnej energochłonności budynków" Zadanie badawcze nr 5: „Zoptymalizowanie zużycia energii elektrycznej w budynkach" Politechnika Śląska PBS-5/RM$1 / 2010$.

[23] Szczechowiak E., Porowski M.: Klimatyzacja i chłodnictwo, www.ee.put.poznan.pl/zasoby/kich/06klimaichl.pdf

[24] Szczechowiak E., Porowski M Komfort klimatyczny a projektowanie architektoniczne http://www.ee.put.poznan.pl/ zasoby/kich/06klimaichl.pdf, s.28

[25] Wargocki P., Wyon D.P, Fanger P.O.: the performance and subjective responses of call-centre operators with new and used supply air filters at two outdoor air supply rates. 2004 Indor Air, Vol. 14, Suppl. 8, pp. 7-16.

[26] Wyon D. P., Wargocki P.: Room temperature effects on office work. Part of: Creating the Productive Workplace. Taylor \& Francis. London 2006.

[27] Wyon D.P., Fang L., Meyer H.W., Sundell J., Weirsoe C.G., Sederberg-Olsen N., Tsutsumi H., Agner T., Fanger P.O.: Limiting criteria for human exposure to low humidity indoors. Proc. Of Indor Air 2002/202, Monterey, vol. 4, pp. 400-405. 